\title{
溶接継手部のぜい性き裂伝播経路に関する 解析モデルの提案
}

\author{
正員 角 洋 一*
}

An Analysis of Paths of Brittle Cracks Propagating along Butt Welded Joints

by Yoichi Sumi, Member

\begin{abstract}
Summary
In order to preserve the structural integrity against brittle fracture, structural materials should be selected based on the proper evaluations of the fracture toughness of materials and of the near tip field parameters of a crack by an appropriate stress analysis. In welded structures there exist some difficulties in achieving the procedure. The precise evaluation of the fracture toughness of materials is not a simple task, if a welding process induces the spatially distributed inhomogeneous material degradation such as the locally restrained decrease of the fracture toughness in the heat affected zone. Considering a brittle crack initiated and propagating along a welded joint, it sometimes exhibits sharply curved paths and penetrates into the base material, while in other cases it propagates in a straight fashion along the welded joint. It is clear from these observations that the prediction of brittle crack paths is essential for the evaluation of fracture toughness of welded structures.

In the present paper a mathematical model is proposed for the crack path prediction, in which the combined effects of applied stresses, welding residual stresses, and material degradation in the so-called heat affected zone are taken into account. In the present model a homogeneous fracture toughness is assumed in both the base and weld materials, where the crack path is predicted by the local symmetry criterion $\left(K_{\mathrm{II}}=0\right)$ based on the first order perturbation solution of a slightly kinked and curved crack. When a curved crack propagating in a weld material intersects the heat affected zone which is modelled as a line degradation zone, a quastion arises as to whether the crack extends along the heat affected zone, or whether it penetrates into the base material. Since the local symmetry criterion does not work at this point, the crack growth direction is predicted by the minimum principle of the total potential energy. The relevant energy calculations can easily be performed by using the second order perturbation solution of a kinked crack.

Numerical results show that if brittle fracture occurs under a relatively low applied stress in comparison with the longitudinal welding residual stress, and if the average material degradation along the heat affected zone is small, crack paths tend to deviate from the welded joint. This is the case actually observed for brittle fracture of welded plates made of mild steel, where cracks extend in the base material. It is also shown that cracks tend to propagate along the heat affected zone with increasing the applied stress and materials degradation levels, which may possibly simulate certain brittle fracture of welded plates made of high tensile steel.
\end{abstract}

\section{1. 序}

\section{論}

鋼板のぜい性破壊挙動は,ぜい性き裂の発生,伝播および 停止という 3 つの現象に大別して考えることができる1。 近年の破壊力学の進展によって, 材料のき裂発生および伝 播停止に対するじん性の定量的評価が可能となり，材料の

* 横浜国立大学工学部
破壊じん性を表わす各種のパラメータが, 降伏応力, 引張 り強さとともに構造設計に際しての材料選択のひとつの重 要な規準となっている2,3)。

船体構造など薄板溶接構造物では, 溶接部が主要なぜい 性破壊発生の起点になると考えられており，このき裂が溶 接線に沿って伝播する現象は, ひとつの極めて危険なぜい 性破壊のパターンと考えられている ${ }^{4)}$ 。溶接構造物全体と してのぜい性き裂伝播停止特性を評価するためには, 実際 
のき裂伝播経路上におけるき裂停止じん性を定める必要が あり, 溶接ボンド部, 熱影響部のじん性の劣化についても, このような観点から扱う必要があると思われる。即ち，き 裂が実際に熱影響部などの劣化域に沿って伝播する場合に は，この劣化域におけるき裂停止じん性を何らかの方法で 定め，これを規準とした評価が行われるべきであるが，一 方もし, 溶接残留応力の影響などが強く，実際のき裂伝播 経路が劣化域を外れ, 母材内を進展する場合には, 溶接構 造物としてのき裂停止じん性は母材について考えれば十分 であり, 熱影響部の局部的材質劣化を考慮する必要は無い ことになる。このような考え方にもとづく合理的な溶接構 造物のじん性評価を行うためには，局部的な材質劣化域の じん性評価技術の確立とともに，外力，残留応力およびき 裂伝播経路上のき裂停止じん性の変化の影響を含めたき裂 伝播経路の予測技術を確立することが必要であり，これは 今日の計算力学の重要な課題のひとつでもある。

本研究では, 溶接部に発生したぜい性き裂が, 溶接線方 向に伝播する場合について, 外力, 溶接残留応力および溶 接部近傍の材質劣化を考慮した解析モデルを作り，き裂伝 播経路の予測を行う。本解析は, 準静的な近似解析であり 動的影響など実際の破壊現象をすべて取り入れたものでは ないが, 過去の数值解析例などから考えて本方法によるき 裂伝播経路の予測はおおむね実験事実を説明できるものと 思われる5)。本解析モデルでは，母材および溶着金属は一様 な破壊じん性分布をもつものとし，この領域でのき裂伝播 経路の判定は, 折れ曲がりき裂の第 1 攝動解に局所対称性 規準 $K_{\mathrm{II}}=0$ を適用し定める ${ }^{6,7)}$ 。一方，折れ曲がったき裂が 材質劣化を伴う熱影響部などと交差する場合には，その後 このき裂が，材質劣化域に沿って伝播するか，あるいは劣 化域を突きぬけて母材内へ侵入するかを判定しなければな らない。この場合には, 折れ曲がりき裂の応力拡大係数の 第二捸動解 ${ }^{8)}$ を用い，母材および劣化域でのき裂伝播抵抗 値に平衝する荷重レベルを定め, これらのうちエネルギ・ レベルの低い方を実際の伝播形態として定める。

上述の理論モデルに対して，溶着金属の降伏応力に相当 する一定の溶接線方向の残留応力下で, これと直交する外 応力のレベルおよび母材に対する熱影響部の平均的材質劣 化の割合を各種変化させた計算を行い, き裂が残留応力の 影響によって折れ曲がり母材内を伝播するか，あるいは劣 化域に沿って進展するかを検討した。これらの結果から， 溶着金属の降伏応力にくらべ十分小さな応力で低応力ぜい 性破壊が発生し, かつ熱影響部の平均的なじん性低下の割 合が小さい場合には，き裂は母材内を伝播する傾向が強い こと,また反対に, 溶着金属の降伏応力の $50 \%$ 程度の外応 力が溶接線に垂直に作用し，かつ熱影響部のじん性劣化が 大きい場合にはき裂は熱影響部に沿って伝播し易いこと が, 外力, 残留応力, 材質劣化等のパラメー夕を用いて定 量的に明らかとなった。過去に行われた実験によると, 軟
鋼の溶接継手の場合溶接線に沿うべく発生させたぜい性き 裂は, 溶接線から離れた母材内を溶接線に平行に伝播する のに対して, 高張力鋼の同様な溶接線に沿うき裂伝播は, しばしば溶接線熱影響部に生じることが知られてお $\eta^{1,2,4,9,10,11,12,13)}$, 上述の理論モデルによる解析結果は実験 的に知られた傾向を系統的に説明することができるととも に，このような現象に対する定量的予測の可能性を示すも のと云える。

\section{2. 溶接継手部のぜい性き裂伝播形態}

過去の実験結果をもとに巨視的に溶接継手に沿って伝播 するぜい性き裂の伝播形態について考察する。溶接継手部 に作用する外力 $\sigma_{a}$, 溶接残留応力 $\sigma_{r}$ の分布および代表的 なき裂伝播の形態を模式的に Fig. 1 に示す。この図は初期 き裂をボンド部に想定したものになっているが，このほか 溶着金属内の初期き裂など各種の想定が可能である。

Kihara, et $a l^{1,9)}$ の軟鋼の溶接継手に対する ESSO 試験 の結果によると各種の初期ノッチを溶接継手に沿って設け た場合であっても，そのき裂伝播経路は常に Fig. 1 の図中 (a)に示す経路のように母材側を伝播する夕イプになる ことが観察されている。さらに，このき裂経路の溶接線か らの外れは外応力 $\sigma_{a}$ の増加とともに減少する。その後行 われた中形および大形の試験片を用いた溶接部き裂伝播試

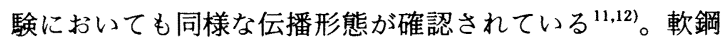
の場合, 溶接熱影響部などの母材に対する平均的なじん性 低下はあまり大きくないので, 主として溶接線方向に作用 する引張り残留応力によってき裂が不安定に屈曲し, 上述

\section{$\sigma_{a}:$ applied stress}

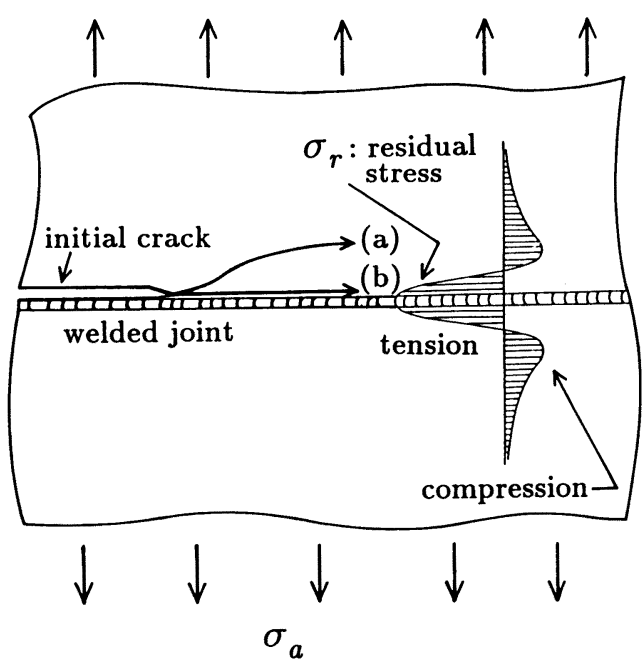

Fig. 1 A brittle crack propagating parallel to a welded joint ; ( a ) crack propagation in the base material; ( b ) crack propagation along the welded joint. 


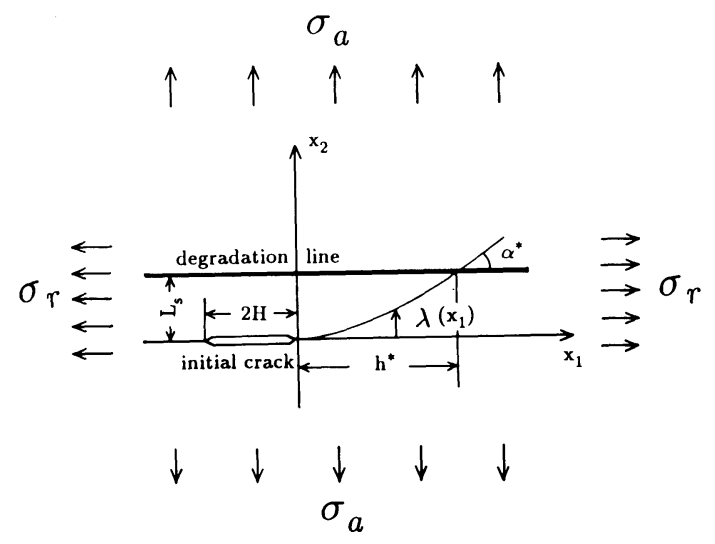

Fig. 2 A mathematical modeling of curved crack propagation along a welded joint.

のような伝播経路をとるものと考えられる5)。このような 場合には, 熱影敏部に沿って存在すると考えられるじん性 劣化域は, 溶接構造物としてのき裂伝播停止能力には直接 の悪影響を及ほさぬ可能性が強い。

一方, 木原・池田によれば 80 キロ級高張力鋼の溶接部に 対するディープ・ノッチ試験でき裂発生後のき裂伝播経路 に軟鋼の場合とは異った挙動が観察されている。この試験 の主目的は破壊の発生特性を定めるためのものであり, 伝 播経路の相違は副次的に得られたものであるが，その後船 体用高張力鋼に対する詳細なき裂伝播試験が日本造船研究 協会を中心に行われた ${ }^{11,12)}$ これらの結果によれば,外応力 $\sigma_{a}$, 溶接条件, 初期き裂の位置を各種変化させると, 軟鎆 の場合と同様に, 溶接部から発生したき裂が, 母材側へ外 れる場合があるだけでなく, 溶接線に沿って直進する場合 もあることが知られる。これらのぜい性き裂伝播形態の相 違には外応力 $\sigma_{a}$ と溶接線位置の残留応力 $\sigma_{r}$ の最大値と の比, 溶接条件による熱影䇾部のじん性劣下の程度の差な ど, 母材および溶着金属の材質, 溶接のプロセスに関係し た要因が複雑に関係しているものと思われる。一般に高張 力鋼の場合, 軟鋼にくらべ溶接による熱影䇾部の母材に対 するじん性低下が大きく，また入熱量が大なるほどこのじ ん性低下は大きいことが知られている。したがって, 高張 力鎆の場合き裂伝播経路に対する材質劣化の影響と残留応 力の影響との関係が軟鋼の場合とは異る可能性がある。こ のような場合には, ぜい性き裂が溶接線に沿って伝播し得 るので, 各種の条件に対してこのような現象が生じる限界 を定め, 母材を伝播する場合には母材のき裂停止じん性值 を，また劣化部に沿って伝播する場合には劣化部のそれを 規準とした強度評価を行う必要が生じてくる。

熱影響部のき裂発生に関する破壊じん性の低下について はニッケル・マレージング鋼あるいは低じん性高張力鋼に ついて母材に対して $10 \%$ 程度の低下がありうることが示
されているが ${ }^{14,15)}$, 船体用構造鋼の溶接部の $K_{\mathrm{IC}}$ 值につい ても文献(13)に詳細なデータがまとめられている。これら は, き裂の発生に関するじん性值であるが, 伝播抵抗值の 劣化域における低下については，一旦伝播を開始したき裂 を所定の経路に沿うよう伝播・停止させることが実験的に 極めて困難なため現状では明確には把握されていないよう である。

\section{3. 溶接部のぜい性き裂伝播形態の解析}

\section{1 解析モデル}

前述した過去の実験結果にもとづき解析のための数理モ デルを構成する。溶接部に溶接線に平行な初期き裂を仮定

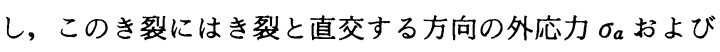
き裂に平行な方向の残留応力の成分が作用するものとす る。初期き裂のその後の伝播形態を定めるために Fig. 2 に 示すき裂先端近傍のモデル化を行う。ここで, 初期き裂の 長さを $2 \mathrm{H}$ とし, その右端に原点, き裂の右向き方向に $x_{1}$ 軸をもつ座標系 $\left(x_{1}, x_{2}\right)$ を導入する。初期き裂からのき裂 伝播は便宜上右端からのみ生じるとし, その非直線状伝播 の $x_{1}$ 軸からの外れを $\lambda\left(x_{1}\right)$ によって表わす。き裂経路が屈 曲すると, き裂は熱影響部などの劣化域と交差する。この 劣化域は, 溶接線の両側に数ミリの幅をもちかつその内部 で不均一なじん性分布をもつが本モデルではこれを溶接線 に平行な線状の破㙗じん性低下域と近似した。また，母材 および溶着金属の破壊じん性值に対応する限界エネルギ解

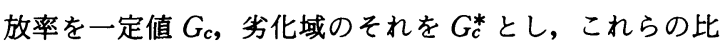
$G_{c}^{*} / G_{c}$ で無次元化された劣化の割合を表現する。初期き裂 と劣化域の距離を $L_{s}$ とすると, Fig. 2 に示すようにき裂

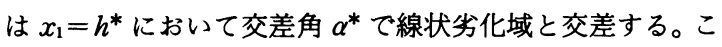
のき裂先端部近傍の局部モデルでは溶接線方向の残留応力 成分 $\sigma_{r}$ はほほ一定と考えてよいので, 以下の解析に際し ては $\sigma_{r}$ は一定值としている。なお, 本解析は, 準静的弾性 き裂進展解析でありき裂伝播に関係する動的影響およびき 裂先端の塑性変形の影響は考慮していない。

初期き裂先端部の応力場のパラメータとしては文献 $[6$, 7] で示したように Irwin-Williams の展開の最初の数項の 係数を用いる。即ち, モード I およびモードIIの応力拡大 係数 $k_{\mathrm{I}}, k_{\mathrm{II}}$, き裂に平行な一定直応力成分 $T$, およびき裂先 端からの距離の平方根に比例するモード I およびモード II の係数 $b_{\mathrm{I}}$ および $b_{\mathrm{II}}$ である。これらの值および同じく文献 [7]で定義したき裂進展後の応力拡大係数に及ほす主き裂 サイズなど境界影箘を表わす係数 $\bar{k}_{i j}$ は Fig. 2 に示す外力 条件に対して

$$
\begin{aligned}
& k_{1}=\sigma_{a} \sqrt{\pi H}, T=\sigma_{r}-\sigma_{a}, b_{1}=\frac{3}{4} \sigma_{a} \sqrt{\pi / H}, \\
& k_{11}=b_{11}=0, \\
& \bar{k}_{11}=\bar{k}_{22}=-\frac{1}{8 H}, \bar{k}_{12}=\bar{k}_{21}=0,
\end{aligned}
$$


と定まる。

\section{2 一様材質中のき裂伝播経路}

初期き裂先端が Fig. 2 に示すように一様材質中にある 場合には，このき裂伝播経路はき裂先端部の局所対称性の 条件 $\left(K_{\mathrm{II}}=0\right)$ から定めることができる ${ }^{6,7)}$ 。き裂の経路 $\lambda\left(x_{1}\right)$ を文献 [ 6 ] と同様に

$$
\lambda\left(x_{1}\right)=\alpha x_{1}+\beta x_{1}{ }^{3 / 2}+\gamma x_{1}^{2}+O\left(x_{1}{ }^{5 / 2}\right)
$$

と近似する。ここに， $\alpha, \beta, \gamma$ は形状パラメータである。こ こで文献 $[6,7]$ で定めた非直線状き裂先端の応力拡大係数 の第一捸動解を計算し，さらに局所対称性の条件を満足す るようにせん断型の応力拡大係数 $K_{\mathrm{II}}$ を恒等的に 0 とする と (2) 式の形状パラメータが,

$$
\begin{aligned}
\alpha= & -2 k_{\mathrm{II}} / k_{\mathrm{I}} \\
\beta= & \frac{8}{3} \sqrt{\frac{2}{\pi}}\left(T / k_{\mathrm{I}}\right) \alpha \\
\gamma= & -\left(k_{\mathrm{II}} \bar{k}_{22}+k_{\mathrm{I}} \bar{k}_{21}+\frac{b_{\mathrm{II}}}{2}\right) \frac{1}{k_{\mathrm{I}}}+\left[\left\{k_{\mathrm{I}}\left(2 \bar{k}_{22}-\bar{k}_{11}\right)\right.\right. \\
& \left.\left.+\frac{b_{\mathrm{I}}}{2}\right\} \frac{1}{2 k_{1}}+4\left(T / k_{\mathrm{I}}\right)^{2}\right] \alpha
\end{aligned}
$$

と定まる。

（1）式を（ 3 )式に代入すると $\alpha=\beta=\gamma=0$ となり，き裂 は直進するとの結果を得るが，これはこの力学系がき裂線 に関して完全な対称性を有している場合に限る。実際の現 象には必ず不完全性を伴うので, き裂経路がこの不完全性 に敏感な場合にはき裂の届曲が生じることになる。いま， この不完全性の要因として外力の不整による初期き裂先端 の微小な, しかし非ゼロのせん断型応力拡大係数 $k_{11}$ を仮 定する。このとき $\left|k_{\mathrm{II}}\right| \ll k_{1}$ であるから ( 3 ) 式より微小折れ 曲がり角 $\alpha(|\alpha| \ll 1)$ の屈折がき裂先端に生ずる。き裂の進 展に伴い, き裂進展方向が初期き裂の方向へと復原する場 合を安定，そうでない場合を不安定と定義すると，き裂伝 播経路の安定性はき裂経路の表示式 (2)の第 2 項, 第 3 項 の和の符号によって

$$
D_{s}=B_{s}+C_{s} \sqrt{h / L_{s}}\left\{\begin{array}{l}
<0: \text { stable } \\
>0: \text { unstable }
\end{array}\right.
$$

と定まる。ここにき裂経路の不安定度を表わすパラメータ $B_{s}$ および $C_{s}$ は

$$
\begin{aligned}
& B_{s}=\frac{8}{3} \sqrt{\frac{\pi}{2}}\left(T / k_{1}\right) L_{s}^{1 / 2} \\
& C_{s}=\left[\left\{k_{1}\left(2 \bar{k}_{22}-\bar{k}_{11}\right)+\frac{b_{\mathrm{I}}}{2}\right\} \frac{1}{2 k_{\mathrm{I}}}+4\left(T / k_{\mathrm{I}}\right)^{2}\right] L_{s}
\end{aligned}
$$

と与えられる ${ }^{16,17)}$ 。

（1）式を( 5 )式に代入し, 本き裂伝播モデルの外応力お よび初期き裂長さを変化させた場合のき裂経路安定性を検 討する。負荷応力と引張り残留応力の最大値との比 $\sigma_{a} / \sigma_{r}$ を $0.25,0.50$ とし, 初期き裂の半長 $H$ を各種変化させた 場合のき裂経路不安定性を表わすパラメー夕 $B_{s}$ および $C_{s}$ の值を Fig. 3 に示す。両パラメータとも常に正であり き裂経路は不安定であるが, 特に負荷応力 $\sigma_{a}$ が残留応力

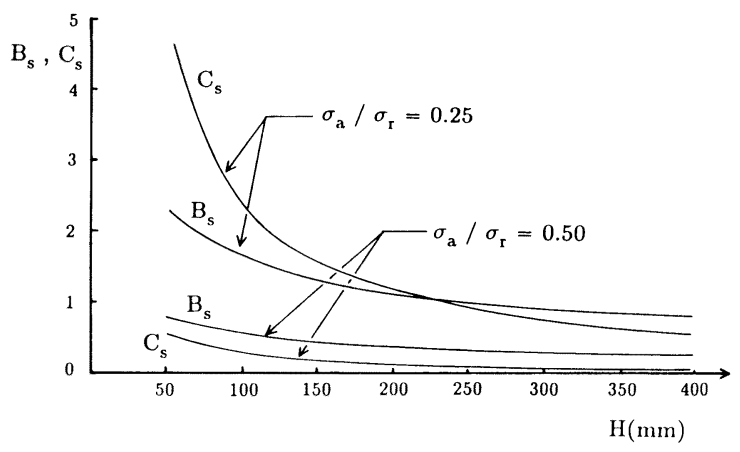

Fig. 3 Crack path destabilizing factors $B_{s}$ and $C_{s}$.

$\sigma_{r}$ にくらべて小さく，かつ初期き裂の寸法が小さい場合ほ ど両パラメータの值が増大する。これは溶接線近傍に存在 する小さな初期き裂が，何らかの理由で低応力で伝播を開 始した場合には, その後の伝播経路が不安定に届曲する傾 向をもつことを意味している。

\section{3 き裂が破壊じん性劣化域と交差する場合の 伝播経路}

前節の考察から材質を一様と仮定する限り, 溶接線に沿 うき裂伝播経路は不安定になることが予測されるが, 本モ デルではこのような非直線状のき裂進展の結果ぜい性き裂 が溶接熱影響部を模凝した線状のじん性低下域に交差する ことになる。き裂がおおむね $\alpha^{*}=30^{\circ}$ 以下の浅い角度で劣 化域と交差する場合には, 文献 $[8]$ で導いた折れ曲がりき 裂の先端の応力拡大係数の第二摂動解が有効なので，この 解をエネルギ的な破壊条件に適用すると, 劣化の程度 $G_{c}^{*} /$ $G_{c}$ とき裂の劣化域との交差角 $\alpha^{*}$ の関係が得られ,

$G_{c}^{*} / G_{c}<1-\alpha^{* 2} / 2$

なる場合に限りき裂が劣化域を伝播するという条件が定ま る。

\section{4 解析結果および考察}

本節では, 3.2 および 3.3 節で述べたき裂伝播経路の判 定規準にもとづき，3.1節で示した溶接部を伝播するぜい 性き裂のモデルに対して外力, 材質劣化の程度, 初期き裂 の寸法など各種の条件を変化させた場合の伝播経路予測を 行い, 溶接部におけるぜい性き裂の伝播形態に及ほす各種 要因の影響を定量的に解明する。

本解析では, 物体形状については初期き裂の半長を $H=$ $100,200,300,400,500 \mathrm{~mm}$ の 種類, 初期き裂と材質劣化 部の距離は溶接ビート幅のオーダと考え $L_{s}=25,50 \mathrm{~mm}$ の 2 種類の計 10 種類を考える。力学的条件としては, 外応 力 $\sigma_{a}$ と残留応力の最大值 $\sigma_{r}$ との比を, $\sigma_{r}$ がほほ降伏応力 程度になることを考慮して $\sigma_{a} / \sigma_{r}=0.25,0.50$ の 2 種類と する。初期不整については, 初期き裂の先端に外力の不整 による微小なせん断型応力拡大係数 $k_{\mathrm{II}}$ が存在し, これに よって折れ曲がり角 $\alpha=0.5^{\circ}, 1.0^{\circ}, 1.5^{\circ}, 2.0^{\circ}, 2.5^{\circ}, 3.0^{\circ}$ なる 6 種類の微小角の初期き裂届折が生ずるとする。 


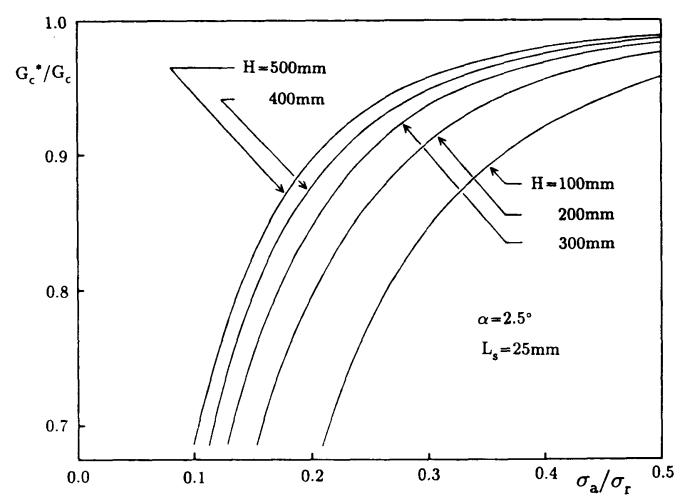

Fig. 4 Critical relations between the material degradation and the applied stress for various initial crack lengths; cracks penetrate into the base material for the conditions corresponding to the upper left regions with respect to the curves.

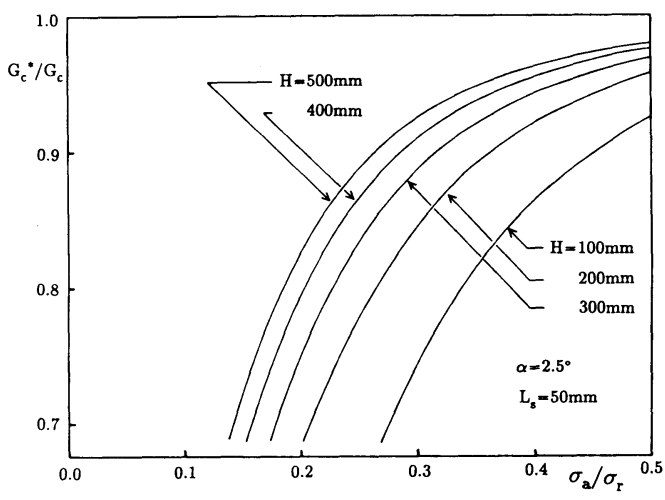

Fig. 5 Critical relations between the material degradation and the applied stress for various initial crack lengths; cracks penetrate into the base material for the conditions corresponding to the upper left regions with respect to the curves.

上述の初期条件のもとにその後のき裂進展経路を定める には (2),（3)両式を用いればよい。き裂が届曲し, 劣化 域と交差する場合, き裂と線状劣化域との交差角 $\alpha^{*}$ は ( 2 ) 式を $x_{1}$ について微分し,

$$
\alpha^{*}=\lambda^{\prime}\left(h^{*}\right)
$$

と定まる。したがって, 劣化域に沿うき裂伝播に対する破 壊じん性が（6)式を満す程度に低下していれば，き裂はそ の後,この劣化域に沿って伝播することになる。（6)式を 満さぬ場合には当然き裂は高じん性側の母材に侵入する。 この考え方にもとづき, き裂が母材へ侵入するか劣化域に 沿って伝播するのか限界を与える限界曲線を定めることが できる。Fig. 4 および Fig. 5 に $\alpha=2.5^{\circ}$ ，それぞれ $L_{s}=25$, $50 \mathrm{~mm}$ の場合についての限界曲線を示す。この図では外応
力と残留応力の比 $\sigma_{a} / \sigma_{r}$ を横軸に，母材に対する劣化域の 材質劣化の割合 $G_{c}^{*} / G_{c}$ を緹軸にとり，初期き裂長さをパ ラメータとして表示している。各種の条件がこれらの曲線 の右下側に入る場合には，き裂は劣化域に沿って伝播する が，一方これらの曲線の左上側に入る場合には母材に入る ことになる。

これらの図から，母材に対する熱影響部などの材質劣化 の程度が大きく，かつ外力と溶接線方向の残留応力の最大 値との比が大なるほどき裂は劣化域に沿って伝播し易いと いう定性的な説明が可能になるとともに，この現象に対す る力学的および材質に関係するパラメー夕の相互効果をあ る程度定量的に表現することも可能になった。2 章で述べ た軟鋼および高張力鋼で観察される溶接部のき裂伝播形態 の相違も，溶接残留応力および劣化部のき裂伝播抵抗值に 関する詳細な実験データがあれば本理論によって定量的に 説明が出来る可能性がある。

Fig. 4 および Fig. 5 の初期き裂長さを変化させた計算結 果を見ると, 初期き裂が長いほど劣化域に沿ったき裂伝播 の可能性が高く,これは一旦劣化域に沿って伝播し始めた ぜい性き裂は母材側へ侵入する可能性が小さいことを示し ている。

初期折れ曲がり角 $\alpha$ の影響を検討するため $H=100$ $\mathrm{mm}, L_{s}=50 \mathrm{~mm}$ の場合について $\alpha$ をパラメー夕とした限 界曲線を Fig. 6 に示す。折れ曲がり角 $\alpha$ が大きくなれば自 明のことながらき裂が母材側へ侵入する傾向は強くなる。 実際の溶接線において $\alpha$ の值をどの程度にとるべきか, 現 在のところあまり明確な指針がないので，溶接部における き裂伝播経路の実験データを統計的に処理するなどして今 後適当な值を定める必要がある。

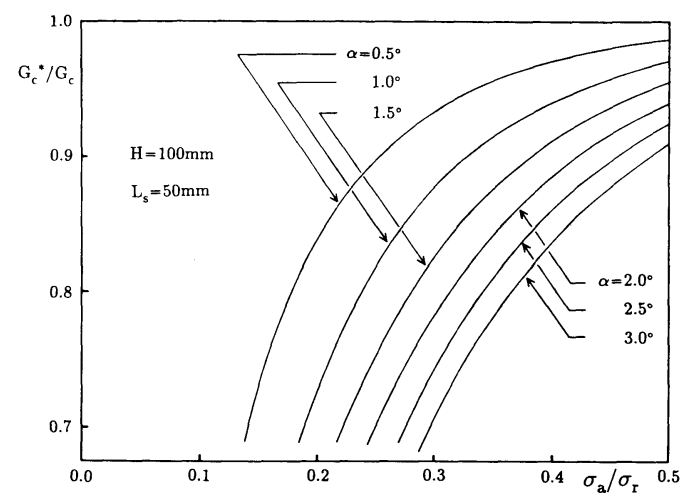

Fig. 6 Critical relations between the material degradation and the applied stress for various initial small kink angles; cracks penetrate into the base material for the conditions corresponding to the upper left regions with respect to the curves. 


\section{4. 結}

\section{論}

溶接部を伝播するぜい性き裂の数理モデルを構成し，き 裂伝播形態を支配するいくつかの力学的・材質的要因をパ ラメトリックに変化させた解析を行った。得られた結論は 以下の通りである。

（i ）初期き裂に垂直な方向に作用する外応力，溶接線に 平行な方向に作用する残留応力および熱影響部などの材質 劣化が, き裂伝播経路に及ほす影響を解析するためのモデ ルを提案し, き裂が劣化域に沿って伝播する場合と母材に 侵入する場合の限界を定量的に定めた。

（ii） 母材に対する熱影響部のじん性低下が大きく，かつ 外応力と溶接残留応力の比が大なるほどき裂は劣化域に沿 って伝播する傾向が強い。この傾向は, 軟鋼と高張力鋼の 溶接部のぜい性き裂伝播形態の相違と密接に関係している と思われる。

（iii）初期き裂が長いほどき裂の直進性は強まるので，一 旦溶接線材質劣化部に沿って伝播を開始したぜい性き裂が 屈曲し母材側に侵入する可能性は小さい。

（iv）本理論によるき裂伝播経路は不整量として採用した 初期折れ曲がり角に関係するので, 今後実際の溶接継手に おいてどの程度の值を用いて伝播経路の予測を行うべきか 検討を要する。

（v） 本理論によるき裂伝播経路予測法が確立すれば，溶 接継手のき裂停止じん性として母材のそれを採用すべき か, 材質劣化部のそれを採用すべきかが明確となり,より 合理的な溶接構造物設計の展開が期待できる。

\section{謝辞}

本研究に際して貴重な御助言をいただいた横浜国立大学 教授板垣浩先生にお礼申し上げます。また，論文の取りま とめの際に御協力いただいた本学道山俊一技官, 卒業研究 として 3.4 節の数值計算を手伝っていただいた高橋学・藤 家達の両君に謝意を表します。

\section{参考文 献}

1) Hall, W. J., Kihara, H., Soete, W., and Wells, A. A.: Brittle fracture of welded plate, PrenticeHall, Englewood Cliffs (1967).
2) Munse, W. H. : Brittle fracture in weldments, in Fracture Vol. IV, Academic Press, New York (1969), pp. 371-438.

3）金沢・越賀：脆性破壊 2 , 培風館, 東京(1977).

4）木原・池田：脆性破壊の発生に関する研究(第 3 報), 造船協会論文集，第 120 号 (1966), pp. 207-220.

5）角・大橋：溶接残留応力場におけるき裂伝播経路の 数值予測とぜい性破壊挙動に関する考察, 日本造船 学会論文集, 第 162 号 (1987), pp. 415-423.

6）角：き裂成長形態の予測に関する基礎研究(その 1 ), 日本造船学会論文集, 第 149 号 (1981), pp. 219 -225 .

7) Sumi, Y.: A note on the first order perturbation solution of a straight crack with slightly branched and curved extension under general geometric and loading condition, Engng. Fracture Mech. 24 (1986), pp. 479-481.

8）角：非直線状き裂の第二摂動解とき裂伝播経路, 日 本造船学会論文集, 第 165 号 (1989), pp. 245-251.

9) Kihara, H., Yoshida, T., and Oba, H. : Initiation and propagation of brittle Fracture in welded steel plate, IIW Document No. X-217-59(1959).

10）池田：新しい鋼材の脆性破壊の諸問題, 造船協会誌, 第 460 号 (1967), pp. 415-421.

11）日本造船研究協会第 147 研究部会報告書, 研究資料 208(1974), 229(1975), 244(1976).

12）日本造船研究協会第 153 研究部会報告書, 研究資料 234 (1975)，249(1976)，267(1977).

13）日本造船研究協会第 169 研究部会：船体構造の破壊 管理制御設計指針，（1983）。

14) Kies, J. A., Smith, H. L., Romine, H. E., and Bernstein, H.: Fracture testing of weldments, ASTM STP 381(1965), pp. 328-353.

15) Wessel, E. T. and Hays, L. E. : Fracture characteristics of some high-strength, weldable, structural steels, Welding Journal, 42 (1963), Res. Suppl., p. 512-S.

16）角・籠橋：き裂成長形態の予測に関する基礎研究(そ の 2 ), 日本造船学会論文集, 第 152 号 (1982), pp. 397-404.

17) Sumi, Y.: Crack path stability in tapered DCB specimens, in Fracture control of engineering structures Vol. II, EMAS, Warley (1987), pp. 1413 -1422 . 